\title{
The TAC and MDA Values in Patients with Chronic Suppurative Otitis Media
}

\author{
ROXANA SERBAN, CODRUTA BADESCU*, DRAGOS OCTAVIAN PALADE*, MAGDA BADESCU, \\ CATALINA FILIP, IULIA ELENA DIACONU, ARIADNA MOCREI*, DANISIA HABA, MIHAIL DAN COBZEANU \\ Grigore T. Popa University of Medicine and Pharmacy, 16 Universitatii Str., 700115, Iasi, Romania
}

\begin{abstract}
The oxidative stress is linked to many chronic diseases. The aim of the study was to assess the oxidative stress in chronic suppurative otitis media. The prospective study included a group of 60 patients with different forms of chronic suppurative otitis media (CSOM), cholesteatoma recidivism and a control group of 30 healthy people. The total antioxidant capacity (TAC) and malondialdehyde (MDA) concentrations were determined in serum of thepatients. We noticed a significant lower mean of TAC levels $(p<0.001)$ in patients with chronic suppurative otitis media (CSOM) with and without cholesteatoma compared to the control group. The MDA had significantly higher mean values $(p<0.001)$ compared to the healthy group. The imbalance of antioxidant systems to oxidizing molecules plays an important role in the pathogenesis of CSOM with and without cholesteatoma.
\end{abstract}

Keywords: oxidative stress, chronic otitis media, cholesteatoma, malondialdehyde

Chronic suppurative otitis media (CSOM) represents a persistent inflammation process of the middle ear. CSOM usually starts as a complication after frequent episodes of acute otitis media. Cholesteatoma represents an abnormal accumulation of keratinized epithelium found in the middle ear [1, 2].

The prevalence of CSOM is between 65 and 330 million people, and $60 \%$ have significanthearing impairment. The incidence of cholesteatoma is assessed to be 9 per 100000 people [3].

The balance between the oxidative action of free radicals and the level of antioxidants characterize the resistance of the body. In many pathological conditions, there is an acceleration of reactive oxygen species (ROS) formation, resulting in an imbalance between oxidative factors and protective antioxidant systems. This explains the involvement of free radicals in many diseases: respiratory diseases, kidney problems, hypertension, neuro-degenerative diseases (Alzheimer's, Parkinson's), diabetes, asthma, carcinogenesis, inflammatory rheumatic diseases, cataract and macular degeneration $[4,5]$.

ROS can alter the function and structure of proteins by modifying amino acid residues, inducing proteins dimerization and interacting with other metal complexes. Oxidative changes of amino acids in the functional domain of proteins may involve manypathways[6]. Cellular targets for free radical actions include lipids, macromolecules, proteins and DNA [7].

\section{Experimental part \\ Material and method}

The study which included a group of 60 patients aged between 9 and 58 years diagnosed with CSOM with and without cholesteatoma, was performed in the Clinical Rehabilitation Hospital lasi between 2017-2018. Of those, 28 patients had CSOM without cholesteatoma, 22 with CSOM with cholesteatoma, and 11 with cholesteatoma recidivism. The inclusion criteria in the study were: radiological (CT or CBCT study) and clinical diagnosis of CSOM, patients without any known comorbidities, informed consent to participate in the study. Exclusion criteria were: acute or chronic pathology excepting ear disease, history of alcohol consumption and smoking, medication consuming, including vitamins.
The control group was representedby 30 healthy people, aged between 6 and 54 years old.

The patients were divided into 4 groups: group $M$ represented healthy people, group $\mathrm{C}$ includes patients with CSOM with cholesteatoma, group $\mathrm{R}$ included patients diagnosed with cholesteatoma recidivism and group 0 represented patients with CSOM without chBlood samples for analysis were collected betw een 7 and $10 \mathrm{AM}$, after 12 $h$ of fasting, into empty tubes and stored on ice at $4^{\circ} \mathrm{C}$ The serum was afterwards separated from the cells by centrifugation ( $3000 \mathrm{rpm}$ for $10 \mathrm{~min}$ ). Serum samples were stored at $-20^{\circ} \mathrm{C}$ until they were used.All patients underwent surgical treatment.

\section{Determination of TAC}

The serum TAC levels were measured using the TAC Assay Kit from Sigma Aldrich, for research and manual use, according to the instructions. The antioxidant capacity was measured in Trolox equivalents.

\section{Determination of MDA}

The lipid peroxidation was determined by using the MDA Assay Kit from Sigma Aldrich for research and manual use, which is based on the reaction of MDA with the thiobarbituric acid to form a colorimetric product, proportional to the MDA concentration. We used the colorimetric method and we measured the absorbance at $532 \mathrm{~nm}$.

Statistical analysis was performed using the SPSSprogram version 18.0.

\section{Results and discussions}

The Skewness / Kurtosis tests $(-2<p<2)$ showed that the TAC and MDA values were homogeneous.

TAC levels in the study group varied between 25.902 $\mathrm{mmol} / \mu \mathrm{L}$ and $28.411 \mathrm{mmol} / \mu \mathrm{L}$ in patients with cholesteatoma recidivism, $26.908 \mathrm{mmol} / \mu \mathrm{L}$ and 28.608 $\mathrm{mmol} / \mu \mathrm{L}$ in patients with CSOM with clinic and radiologic cholesteatoma (fig.1) and $25.815 \mathrm{mmol} / \mu \mathrm{L}$ and 29.313 $\mathrm{mmol} / \mu \mathrm{L}$ in patients with CSOM without cholesteatoma. In the healthy groups, TAC values ranged between 27.834 $\mathrm{mmol} / \mu \mathrm{L}$ and $31.185 \mathrm{mmol} / \mu \mathrm{l}$ with a mean of 29.401 $\mathrm{mmol} / \mu \mathrm{L}$ (table 1 ).

\footnotetext{
* email:codruta.badescu@gmail.com; drpalade@gmail.com; ariadna.mocrei@gmail.com
} 

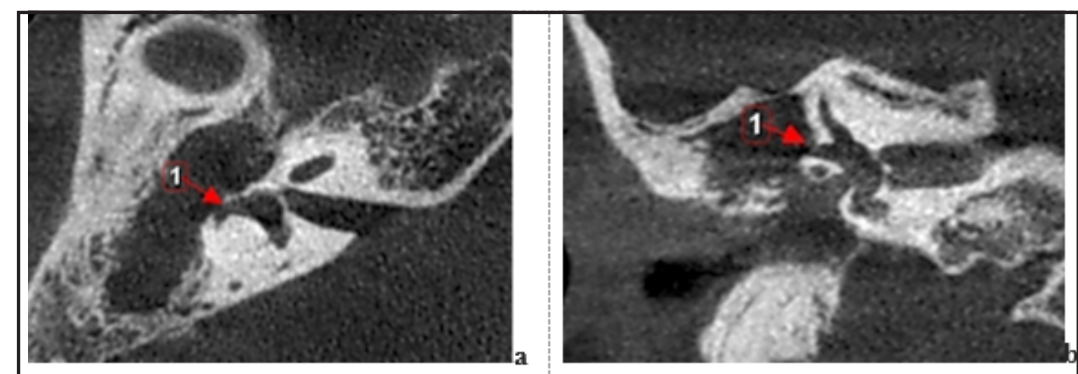

Fig.1 A 28-year-old male with a history of

chronic ear discharge on the right side and retraction pocket at otoscopy. CBCT shows a large pars flaccida cholesteatoma with opacification of Prussak space, ossicular erosion and displacement of incus body and short process (yellow arrow).

$\mathbf{a}$. Axialand b. coronal CBCT image shows

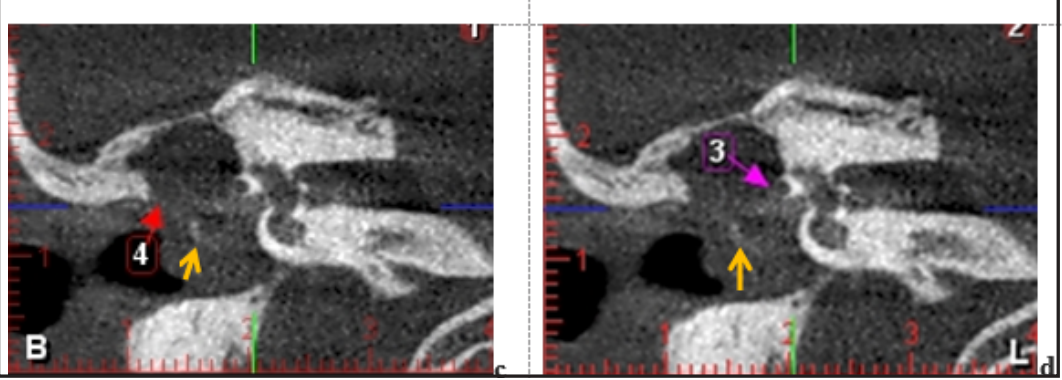
opacification and enlargement of antral cavity with erosion and fistula of the capsule of the horizontal

semicircular canals. Coronal CBCT images

$(\mathbf{c}, \mathbf{d})$ shows opacification of the meso- and

epitympanon with erosion of the scutum (red arrow) and the second portion of the facial nerve canal (mauve arrow).

\begin{tabular}{|c|c|c|c|c|c|}
\hline Parameter & & Group M & Group R & Group C & Group O \\
\hline Number & & 30 & 11 & 21 & 28 \\
\hline \multicolumn{2}{|l|}{ Mean } & $29.401^{-}$ & $27.210^{2}$ & $27.657^{\mathrm{a} / \mathrm{min}}$ & 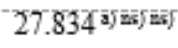 \\
\hline \multicolumn{2}{|l|}{ Median } & 29.162 & $27.111^{-}$ & 27.519 & 28.045 \\
\hline \multicolumn{2}{|l|}{ Standard Deviation } & 1.036 & $1.054^{-}$ & 0.514 & 1.094 \\
\hline \multicolumn{2}{|l|}{ Variance } & 1.073 & $1.111^{-}$ & 0.264 & 1.197 \\
\hline \multicolumn{2}{|l|}{ Skewness Test } & -0.037 & $0.029^{\circ}$ & 0.341 & -.0577 \\
\hline \multicolumn{2}{|l|}{ Std. Error of Skewness } & 0.427 & 0.661 & 0.501 & 0.441 \\
\hline \multicolumn{2}{|l|}{ Kurtosis } & -1.243 & -1.657 & -0.773 & -0.586 \\
\hline \multicolumn{2}{|l|}{ Std. Error of Kurtosis } & 0.833 & 1.279 & 0.972 & 0.858 \\
\hline \multicolumn{2}{|l|}{ Minimum } & 27.834 & 25.902 & 26.908 & 25.815 \\
\hline \multicolumn{2}{|l|}{ Maximum } & $31.185^{-}$ & 28.411 & 28.608 & 29.313 \\
\hline \multirow[t]{3}{*}{ Percentiles } & 25 & 28.518 & 25.932 & 27.207 & 27.323 \\
\hline & 50 & 29.162 & $27.111^{-}$ & 27.519 & 28.045 \\
\hline & 75 & 30.379 & $28.411^{-}$ & 27.958 & 28.960 \\
\hline
\end{tabular}

Table 1

STATISTICAL DESCRIPTION OF TAC VALUESIN STUDY GROUPS a) $p<0.001$ ns) $p>0.05$
Comparing the group $\mathrm{C}$ and $\mathrm{O}, \mathrm{TAC}$ levelshad significantly lower mean values compared to the control group $(27.519 \mathrm{mmol} / \mu \mathrm{L}, 27.834 \mathrm{mmol} / \mu \mathrm{L}(p=0.496) \mathrm{vs}$ $29.401 \mathrm{mmol} / \mu \mathrm{L} ; p=0.001$ ). The mean level in patients with cholesteatoma recidivismwas slightly lower compared to the level in patients with CSOM with cholesteatoma, but significantly lower compared to the control group $(27.210 \mathrm{mmol} / \mu \mathrm{L}, 27.657 \mathrm{mmol} / \mu \mathrm{L}(\mathrm{p}=$ 0.115 ) vs $29.401 \mathrm{mmol} / \mu \mathrm{L}, \mathrm{p}=0.001$ ) (fig.2).

The MDA values in the patient group with CSOM with cholesteatoma ranged between $0.715 \mathrm{nmol} / \mu$ land $1.150 \mathrm{nmol} / \mu \mathrm{L}$, in the patients with CSOM, was between $0.814 \mathrm{nmol} / \mu \mathrm{L}-0.973 \mathrm{nmol} / \mu \mathrm{L}$ and, in patients with cholesteatoma recidivism, values ranged between $0.875 \mathrm{nmol} /$ $\mu \mathrm{l}$ and $1.1071 \mathrm{nmol} / \mu \mathrm{L}$ as it can be seen in table 2 .

MDA serum level was found to be significantly lowerin the control group compared to the levels observed in patients with CSOM with and without cholesteatoma ( 0.948 , 0.891 ( $p=0.01$ ) vs. $0.625, p=0.001$ ). The mean level in patients with cholesteatoma recidivismwas slightly higher

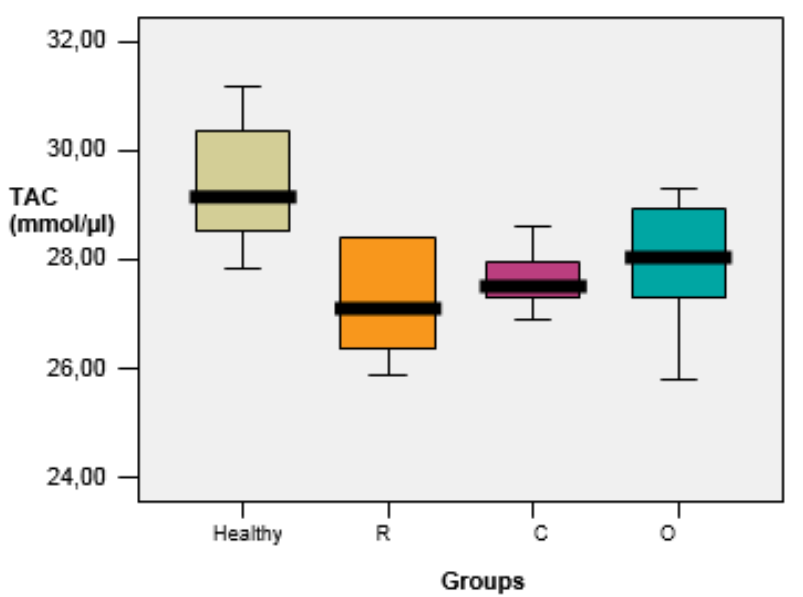

Fig. 2. TAC mean values in study groups: healthy control group, R- patients with cholesteatoma recidivism, C- represents patients with CSOM with cholesteatoma, 0- patients with CSOM without cholesteatoma 


\begin{tabular}{|c|c|c|c|c|c|}
\hline Parameter & & Lot M & Lot $\mathrm{R}$ & Lot C & Lot $\mathrm{O}$ \\
\hline Number & & 30 & 11 & 21 & $\overline{28}$ \\
\hline \multicolumn{2}{|l|}{ Mean } & 0.625 & 0.979 if & $0.948 \mathrm{a}=\mathrm{as}$ & $0.891^{\mathrm{a} 3 \mathrm{~ns}) \mathrm{b}}$ \\
\hline \multicolumn{2}{|l|}{ Median } & 0.612 & 1.003 & 0.962 & 0.894 \\
\hline \multicolumn{2}{|l|}{ Standard Deviation } & 0.096 & 0.069 & 0.107 & 0.030 \\
\hline \multicolumn{2}{|l|}{ Variance } & 0.009 & 0.005 & 0.011 & 0.001 \\
\hline \multicolumn{2}{|l|}{ Skewness Test } & 0.668 & -0.277 & -0.157 & -0.120 \\
\hline \multicolumn{2}{|l|}{ Std. Error of Skewness } & $0.427^{-}$ & 0.661 & 0.501 & 0.441 \\
\hline \multicolumn{2}{|l|}{ Kurtosis } & -0.189 & -1.203 & 0.363 & 1.557 \\
\hline \multicolumn{2}{|l|}{ Std. Error of Kurtosis } & 0.833 & 1.279 & 0.972 & 0.858 \\
\hline \multicolumn{2}{|l|}{ Minimum } & 0.488 & 0.875 & 0.715 & 0.814 \\
\hline \multicolumn{2}{|l|}{ Maximum } & $0.843^{-}$ & 1.071 & 1.150 & 0.973 \\
\hline \multirow[t]{3}{*}{ Percentiles } & 25 & 0.540 & 0.897 & 0.892 & 0.879 \\
\hline & $50^{-}$ & 0.612 & 1.003 & 0.962 & 0.8894 \\
\hline & 75 & $0.680^{\circ}$ & 1.011 & 1.005 & 0.903 \\
\hline
\end{tabular}

Table 2

STATISTICAL DESCRIPTION OF MDA VALUESIN STUDY GROUPS

$\begin{array}{lll}\text { a) } p<0.001 & \text { b) } p<0.01 \mathrm{~ns})\end{array}$ $p>0.05$

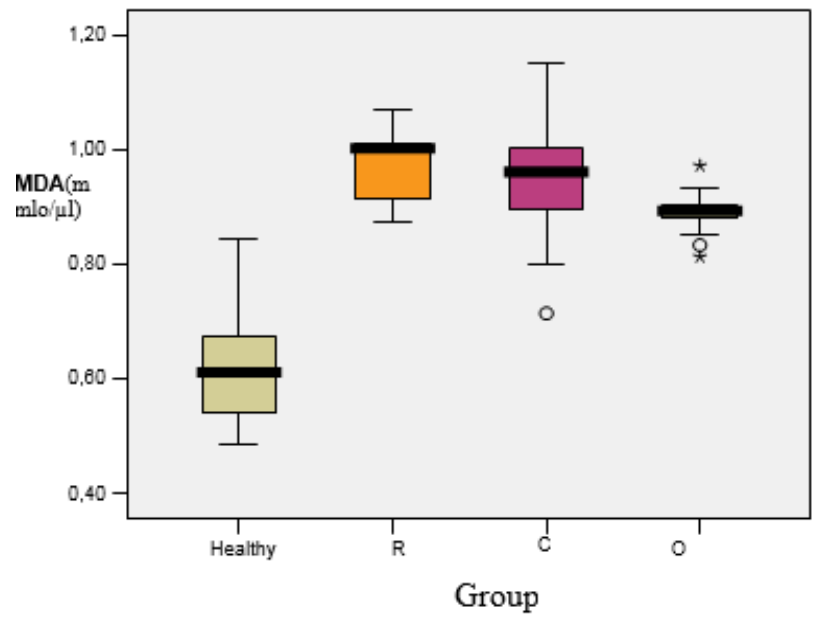

Fig. 3.MDA mean values in study groups: healthy control group, R- patients with cholesteatoma recidivism, C- represents patients with CSOM with cholesteatoma, 0- patients with CSOM without cholesteatoma

compared to patients with CSOM with cholesteatoma, but significantly higher compared to the healthy control group $(0.979,0.948$ ( $p=0.389$ ) vs. 0.625, $p=0.001$ ) (fig.3).

The measurement of TAC is used as an indicator of the system's capacity to counteract oxidative stress-induced injury in tissues and cells [8-10] and it measures the entire antioxidant capacity of a serum sample, not only that of a single antioxidant [11].

Our study showed statistically significant higher levelsof TAC in the healthy group compared to groups with CSOM with or without cholesteatoma, thus demonstrating the existence of an imbalance between oxidant-antioxidant systems. Vascular proliferation, leukocyte infiltration, epithelial thickening, local oedema was linked to the overproduction of oxidants and the tissue damage in the middle ear [12-14]. Some studies show a decrease in the level of oxidative stress by ventilation tube insertion that decrease the local inflammation $[15,16]$.

There are only 2 studies inliterature that measure TAC values in the patients' serumand which highlight, as in our case, high values in patients with CSOM compared to the healthy group [17, 18].

Lipid peroxidation represents the degradation of lipids which appearsas a consequence of oxidative damage and is a very useful marker for highlighting theoxidative stress. The cell membrane has the role of barrier for free radicals. Free radicals must pass through this barrier to interact with intracellular components. Free radicals start lipid peroxidation by removing the hydrogen from alpha-methylene groups of fatty acids in the cell membrane. At the end of the interaction, polyunsaturated acids are subsequently hydrolysed into biological compounds. One of the most important compounds is MDA which reflects the lipid peroxidation magnitude [19-21].

In our study, the MDA levels in the patients group with CSOM with and without cholesteatoma and cholesteatoma recidivism were higher compared to the healthy group, which reflect an increased lipid peroxidation, a result similar to a 2015 study [22]. According to Holecek et al.,lipoperoxidation may be a marker of disease severity in otitis media,being involved in many other otorhinolaryngological diseases [23-25]. Increased MDA values determined in serum and in the middle ear mucosa were found in albino rabbits, with a correlation between results, thus reflecting the tissue damage caused by otitis [26-28].

Yariktas et al. observed that an increased level of free oxygen radicals may contribute to development of otitis media with effusion [29,30] and antioxidant vitamins can be added to the treatment. Cemek et al. found higher MDA serum values in children with acute tonsillitis and acute otitis media and lower values of antioxidant vitamins [31, 32].

\section{Conclusions}

In our study, total antioxidant capacity and lipid peroxidation were evaluated in patients with CSOM with and without cholesteatoma. The serum values of all patients were compared to those of the healthy control group. TAC values weresignificantlylower in patients compared to the healthy group. The lowest values were recorded in those with cholesteatoma recidivism, which may ensue 
from a prolonged tissue damage caused by free radicals. The MDAlevels in the patient groups were significantly higher compared to the healthy group, which reflects an increased lipid peroxidation rate.

\section{References}

1.MORRIS, P. BMJ Clin.Evid., 2012, pii:0507.

2.SERBAN, R., BUTNARU, C., STEFANESCU, H., MARTU, C., COZMA, S., RADULESCU, L., Conference: National ENT, Head and Neck Surgery Conference, 2017,p. 312-315.

3.***World Health Organization. Chronic suppurative otitis media. Burden of illness and management options. 2004. http:// www.who.int/ entity/pbd/deafness /activities/ hearing_care/ otitis_media.pdf.

4.DUANE, P. G., RUBINS, J. B., WEISEL, H. R., JANOFF, E. N.,Infect. Immun., 61, 1993, p. 4392-4397.

5.CAVALERIU, B., MARTU, D., HRITCU, L., MANOLACHE, O., RADULESCU, L., Arch. Biol. Sci., 67, nr. 4, 2015, p. 1297-1302.

6.FILIP, C.,ALBU, E., HURJUI, I., FILIP, C., CUCIUREANU M., POPA, R.F., SOCOLOV, D.G., ALEXA, O., FILIP, A.IS Homocysteine a Marker or a Risk Factor: A Question Still Waits for an Answer. IntechOpen, London, United Kingdom, 2018, doi:10.5772/intechopen.81799.

7.CUZZOCREA, S., RILEY, D.P., CAPUTI, A.P., SALVEMINI, D., Pharmacol. Rev., 53,2001, p. 135-159.

8.ALBU, E., LUPASCU, D., FILIP, C., JABA, I.M., ZAMOSTEANU, N., Farmacia, 61, nr. 6, 2013, p. 1167-1177.

9.ALBU, E., FILIP, C., ZAMOSTEANU, N., JABA, I.M., LINIC, I.S., SOSA, l., Medical Hypotheses, 78, nr. 4, 2012, p. 554-555.

10. FILIP, C., ALBU, E., ZAMOSTEANU N., SILION M., CEJ Med.,5, nr. 5, 2010, p. 620-626.

11.HOFNY EMAN, R.M., HASAN HOWAYDA, I., MOHAMED NAHED, A., BAMATRAFMAYSAA, S., MAHRAN AYMAN M.M., . Egypt. women dermatol. soc.,15, nr. 1, 2018, p. 35-39.

12.YARIKTAS, M., DONER, F., DOGRU, H., YASAN, H., DELIBAS, N.,Int. J. Pediatr. Otorhinolaryngol.,68, nr. 7, 2004, p. 889-94.

13.GEORGESCU, M., VRINCEANU, D., RADULESCU, L., TUSALIU, M., MARTU, C., CURUTIU, C., HUSSIEN, M.D., BUDU, V., Rom.Biotech. Lett.,22, nr. 4, 2017, p.12681-1286.

14.PALADE, D.O., COBZEANU, B.M., ZAHARIA, P., DABIJA, M., Rev Chim (Bucharest), 69, no.5, 2018, p. 1191-1193

15.YILMAZ, T., KOCAN, E.G., BESLER, H.T., YILMAZ, G., GURSEL, B., Otolaryngol. Head Neck Surg., 131, nr. 6, 2004, p. 797-803.

16.COBZEANU, MD, PALADE, D, MANEA, C., CHIRURGIA, 108, no.3, 2013, p. 360-364
17.BAYSAL, E., AKSOY, N., KARA, F., TAYSI, S., TASKIN, A., BILINC, H., et al.,Eur. Arch.Otorhinolaryngol., 270, nr. 4, 2013, p. 1203-1208. 18GARÇA, M.F, ASLAN, M., TUNA, B., KOZAN, A., CANKAYA, H.J J Membr. Biol., 246, nr. 7, 2013, p. 519-524.

19.VALKO, M., LEIBFRITZ, D., MONCOL, J., CRONIN, M.T., MAZUR, M., TELSER, J.,Int. J.Biochem. Cell Biol., 39, nr. 1, 2007, p. 44-84. 20.SHUKLA, G.K., MAHAJAN, A., PANDEY, S., GUJ RATI V.R., VRAT, S., MISHRA, S.C., SHANKER, K.,Boll Chim. Farm., 135, nr. 11, 1996, p. 653655.

21.HARABAGIU, O.E., COSGAREA, M., MOGOANTA, C.A., LEUCUTA, D.C., MANIU, A.A., Rom. J. Morphol. Embryol., 58, nr. 4, 2017, p. 13331338.

22.GARCA, M.F., TURAN, M., AVSAR, B., KALKAN, F., DEMIR, H., KOZAN, A., BOZAN, N.,Clin. Exp.Otorhinolaryngol., 8, nr. 2, 2015, p. 97-101. 23.HOLECEK, V., SLIPKA, J., SOBOTOVÁ, S., SLOUKA, D., ROKYTA, R.,CeskFysiol., 57, nr. 4, 2008, p. 116-22.

24.PALADE, D.O., COBZEANU, B.M., ZAHARIA, P., DABIJA, M., Rev. Chim. (Bucharest), 69, no.6, 2018, p. 1455-1457.

25.BARBOI, OB, PRELIPCEAN, CC, COBZEANU, MD, PALADE, D, ALBUSODA, A, FLORIA, M, CHIRILA, I, DRUG, VL, BALAN, G. Rev Med Chir Soc Med Nat lasi, 119, no.4, 2015, p. 967-973

26.DONER, F., DELIBAS, N., DOGRU, H., YARIKTAS, M., DEMIRCI, M., J. Basic Clin. Physiol. Pharmacol., 13, nr. 1, 2002, p. 33-40.

27.VASILCU, T.F., STATESCU, C., SASCAU, R., ROCA, M., COSTEA, C.F., ZOTA, M., BARARU, I., CONSTANTIN, M.L., MITU, F. Rev. Chim. (Bucharest), 69, no.8, 2018, p. 2283-2286

28.CUCIUREANU, D.I., STATESCU, C., SASCAU, R.A., CUCIUREANU, T., CONSTANTINESCU,V.A., HINGANU, D., PREDA, C., HINGANU, M.V. TURLIUC, M.D., Rev. Chim. (Bucharest), 70, no.2, 2019, p.685-688.

29.BOTNARIU, G., POPA, A., MITREA, G., MANOLE, M., PACURAR, M., ANGHELE, M., CURIS, C., TEODORESCU, E., Rev. Chim. (Bucharest), 69, no.12, 2018, p.3486-3489

30.YARIKTAS, M., DONER, F., DOGRU, H., YASAN, H., DELIBAS, N.,Int. J. Pediatr. Otorhinolaryngol., 68, nr. 7, 2004, p. 889-94.

31.CEMEK, M, DEDE, S., BAYIROĐLU, F., CAKSEN, H., CEMEK, F., YUCA, K., Int. J. Pediatr. Otorhinolaryngol., 69, nr. 6, 2005, p. 823-7. 32.LUCA, A.C., DUCEAC, L.D., MITREA, G., CIUHODARU, M.I., ICHIM, D.L., BACIU, G., BANU, E.A., IORDACHE, A.C., Mat. Plast.,55, no.5, 2018, p.552-554

$\overline{\text { Manuscript received } 21.10 .2018}$ 